\title{
Evaluation of Chipped Cankers for Management of Eastern Filbert Blight
}

\begin{abstract}
Stephanie Heckert, Jay W. Pscheidt, and Steve A. Cluskey, Department of Botany and Plant Pathology, Oregon State University, Corvallis 97331
\end{abstract}

Accepted for publication 22 November 2016.

\section{ABSTRACT}

Oregon harvested 36,000 tons of hazelnuts with a farm gate value of $\$ 135$ million in 2014, primarily from eastern filbert blight (EFB) susceptible cultivars. Cultural management of EFB includes the removing and burning of symptomatic branches to reduce potential sources of inoculum before bud break. As an alternative to burning, chipped cankered branches were studied to determine if they remained a source of inoculum. Branches with or without EFB cankers were coarsely chipped and placed in four piles on the ground at various geospatial locations relative to susceptible host trees. Ascospores were collected above each chipped pile during

\section{INTRODUCTION}

The hazelnut (Corylus avellana L.) industry in Oregon has grown to 42,800 acres due in part to the release of cultivars resistant to Anisogramma anomala (Peck) E. Müll. (Diaporthales), the causal agent of eastern filbert blight (EFB). However, these new cultivars comprise only about 10,000 acres planted within the last 10 years. Most of the production in 2014, estimated at 36,000 tons for a farm gate value of $\$ 135$ million, came from EFB-susceptible cultivars. Keeping these EFBsusceptible acres productive while the industry transitions to resistant cultivars has been a top priority for hazelnut research at Oregon State University.

Once A. anomala infects a tree, the pathogen can be removed only by pruning out the ascospore-bearing cankers (Gottwald and Cameron 1979; Johnson et al. 1996; Pinkerton et al. 1998a; Stone et al. 1992). Pruning EFB cankers before bud break also reduces inoculum and the risk of new infections. However, simply pruning cankers or removing heavily infected trees is not enough to reduce the threat of EFB (Heckert et al. 2013, 2014). Viable ascospores can still be produced from cankers remaining in brush piles adjacent to or within orchards. Burning the symptomatic pruning before bud break in the spring, when hazelnuts are susceptible to new infections, has been recommended (Johnson et al. 1996; Pscheidt and Ocamb 2016).

Agricultural burning is highly regulated in Oregon (Fagundes 2015) and is restricted to days when fire safety and air quality are not compromised. Having found that burning freshly pruned branches during the wet winter months is difficult, growers would prefer to chip these branches within the orchard, leaving the biomass either spread throughout the orchard or as mulch for new plantings. It is unknown if $A$. anomala would survive the process,

Corresponding author: Jay W. Pscheidt. Email: pscheidj@science.oregonstate.edu.

doi:10.1094/PHP-RS-16-0037

(C) 2016 The American Phytopathological Society rain events in the spring of 2012 and 2013. Although ascospore counts were higher above piles containing chipped cankers, they were not significantly different from piles without cankers. However, a small percentage of susceptible hazelnut trees placed amongst, upwind, or downwind of these piles and exposed to ascospores developed EFB cankers. It is advised that when not burning cankered branches, growers should chip these branches prior to bud break in the spring to reduce the risk of potential exposure of the orchard to ascospores.

continue to produce ascospores, and remain a risk to susceptible tissue. The objective of this research was to determine if coarse wood chips generated from EFB-cankered branches and placed under susceptible hazelnut trees would still produce ascospores and cause disease.

\section{TREE EXPOSURE TO A SINGLE AREA OF CHIPPED EFB CANKERS}

A preliminary trial was conducted in 2005 using one large wood-chip pile produced from symptomatic branches. A Vermeer Model 625 chipper was used to chip 'Ennis' and 'Royal' branches with EFB cankers into coarse wood chips on 23 February 2005. These wood chips contained many intact stromata and were placed in a fallow field located at the OSU North Willamette Research and Extension Center, Aurora, OR. The nearest infected commercial hazelnut orchard was $1,067 \mathrm{~m}$ to the southwest. Several hundred infected three to four-year-old research trees were also located $305 \mathrm{~m}$ to the north of this field. Wood chips from cankered branches were spread out in a 6-m circle to a depth of 5 $\mathrm{cm}$.

Healthy, two-year-old 'Ennis' hazelnut trees were planted both inside and outside of the wood-chip area on 3 and 7 March 2005. From the center of the wood-chip area, pairs of trees were planted in a line to the northeast, southeast, southwest, and northwest bearing resemblance to a large "plus" symbol (Fig. 1). Trees were planted either parallel (southwest to northeast) or perpendicular (southeast to northwest) to the prevailing storm track. A total of 14 tree pairs ( 28 trees) were planted $0.9 \mathrm{~m}$ apart inside the woodchip area. A total of 40 tree pairs ( 80 trees) were planted outside the wood-chip area with 20 tree pairs planted $0.9 \mathrm{~m}$ apart followed by 20 tree pairs planted $1.8 \mathrm{~m}$ apart. The closest tree pair outside the wood-chip area was $0.9 \mathrm{~m}$ away while the furthest tree pair was $12.8 \mathrm{~m}$ away.

A rainwater ascospore trap was placed in the center of the wood-chip area and a second trap was placed $15.5 \mathrm{~m}$ to the southwest (upwind) of the wood-chip area as a check. Rainwater 
from the traps was collected on 26 April 2005, 25 May 2005, and 27 June 2005 and processed as described below. Ascospore numbers from each trap represent the cumulative number of ascospores collected from these three dates.

The trap upwind of the wood-chip area collected $3.6 \times 10^{5}$ ascospores $/ \mathrm{m}^{2} /$ day during the initial spring growth period while the trap within the wood-chip area collected $1.4 \times 10^{5}$ ascospores/ $\mathrm{m}^{2} /$ day during the same period. Although spore traps were not replicated, there was little numerical difference in the number of spores collected within or away from the wood-chip area.

The number of EFB cankers that developed on trees planted in the wood-chip area was determined on 26 July 2006. The incidence of infected trees within the wood-chip area averaged $25 \%$ while the incidence ranged from 20 to $35 \%$ for the four directions radiating away from the wood-chip area (including infections on trees up to $12.8 \mathrm{~m}$ away). The incidence of infection did not significantly increase $(P=0.167$ Fisher's LSD, ARM7; Gylling Data Management, Brookings, SD) between the trees located within the wood-chip area or in the four directions radiating outward from the wood-chip area (Table 1).

In a separate, concurrent fungicide efficacy trial, non-chipped, intact symptomatic hazelnut branches were placed above a group of 18 two-year-old trees used as non-treated controls and resulted in $100 \%$ incidence with numerous cankers per tree. The results of the above preliminary study suggested that although chipped symptomatic hazelnut branches could be a potential source of inoculum, the ascospore dose was much lower than the intact symptomatic branches of the fungicide trial. Consistent infection of hazelnut requires a high dose $\left(1 \times 10^{5}\right)$ of ascospores (Johnson et al. 1994). The similar low infection rate within the chipped area (source of inoculum) and distances outside the chipped area in this trial was inconclusive. Results from an intact symptomatic branch pile study (Heckert et al. 2014) indicated more infections on trees within the branch pile (source of inoculum) than at distances away from the branch pile. A new study was conducted to better understand this potential source of inoculum within and at distances around diseased wood-chip piles.

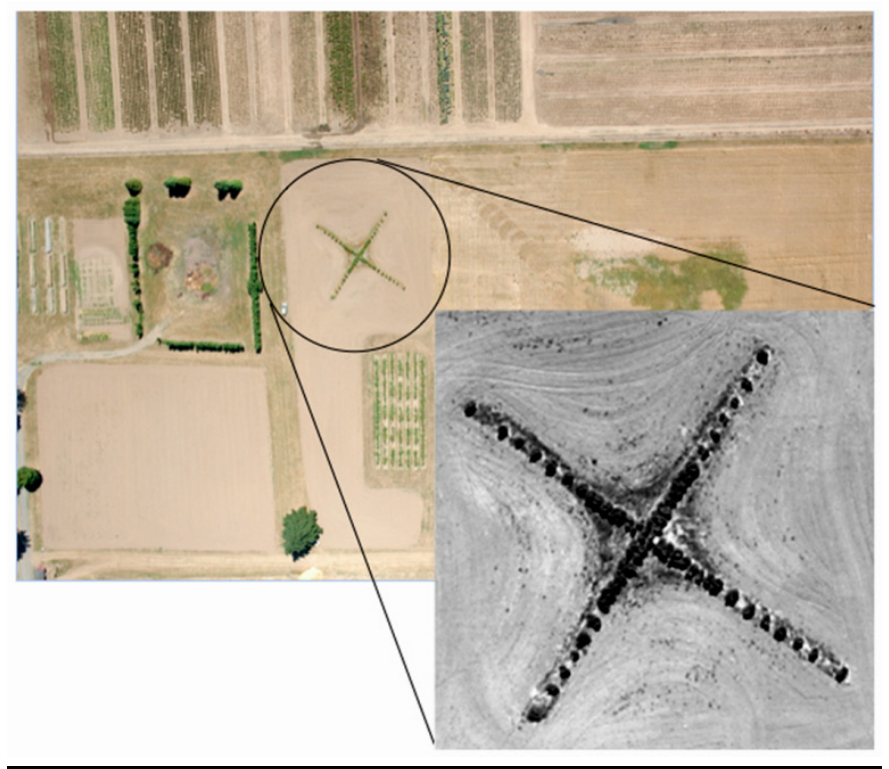

\section{FIGURE 1}

Aerial photo of plot. Wood chips produced from branches with Eastern filbert blight were placed only in the center circle of inset picture. North is to the bottom of the photo.

\section{WOOD CHIPS FROM CANKERED BRANCHES}

Branches bearing cankers and stromata of $A$. anomala were cut from 'Ennis' hazelnut trees prior to bud break from 15 to 17 February 2012 and 6 to 8 February 2013. Only the cankered portion of 125 branches were chipped and used in this study. Cankers were ground using a Vermeer BC 600 brush chipper on 7 March 2012 and 7 March 2013, which resulted in a wood-chip size that ranged from 0.5 to $2.5 \mathrm{~cm}$. Intact stromata were easily observed on these wood chips. Viable ascospores were detected within these stromata using a vital staining technique (Heckert et al. 2013).

\section{ASCOSPORE TRAPPING}

Wood chips from cankered branches were loosely piled in a 0.5 $\times 1.8-\mathrm{m}$ area about $10 \mathrm{~cm}$ thick on 8 March 2012 and 8 March 2013. An equal number of healthy branches were also chipped and piled within 75 to $250 \mathrm{~m}$ of the chip piles from cankered branches. The experiment was conducted at the Botany and Plant Pathology Field Laboratory at Corvallis, OR, and replicated four times at separated locations for a total of eight piles (four woodchip piles from cankered branches paired with four wood-chip piles from healthy branches). The distances between replicates (a set of 2 wood-chip piles) were between 150 to $400 \mathrm{~m}$ and oriented perpendicular to the prevailing storm direction (southwest to northeast).

Rainwater ascospore traps (Pinkerton et al. 1998b, 2001) were placed at 0.15 to $1.2 \mathrm{~m}$ directly above each pile of wood chips. Ascospore traps consisted of a $2.3 \mathrm{~m}$ by $1.3 \mathrm{~cm}$ PVC pipe cut in half lengthwise, supported by two metal posts, and angled at 20 degrees to drain into a covered 16 liter collection bucket. Each bucket contained $30 \mathrm{ml}$ of copper sulfate to inhibit ascospore germination. Rainwater samples were collected from each ascospore trap after each major rainstorm from bud break through shoot elongation (March to June). Rainwater samples were brought back to the laboratory and stored at $6^{\circ} \mathrm{C}$ until being filtered and evaluated for presence of $A$. anomala ascospores (within 48 hours). Ascospore counts represent the cumulative number of ascospores collected from all rain events.

Ascospores collected above wood-chip piles from cankered branches were compared to samples from above wood-chip piles from healthy branches. Differences in ascospore counts were analyzed by $\log$ transforming the data before analysis with Satterthwaite's two-sample t-test (SAS 9.1; SAS Institute Inc., Cary, NC). Significantly more ascospores were found in 2012 above wood-chip piles from cankered branches than above woodchip piles from healthy branches (Table 2). Although more ascospores were found above wood-chip piles from cankered

TABLE 1
$\begin{aligned} & \text { Percent of infected trees within the wood-chip pile } \\
& \text { (produced from Eastern filbert blight cankered branches) }\end{aligned}$
$\begin{aligned} & \text { and extending in two perpendicular transects radiating } \\
& \text { outward in the SW, NE, NW, and SE directions of wood-chip } \\
& \text { area in 2005. }\end{aligned}$
\begin{tabular}{lc} 
Location of trees & Infected trees (\%) \\
Source Pile & 25 \\
SW (Upwind) & 20 \\
NE (Downwind) & 20 \\
NW & 30 \\
SE & 35 \\
$P$-value $=0.167$ & \\
\hline
\end{tabular}

${ }^{\mathrm{x}}$ Tree location was not significantly different according to Fisher's least significance difference (Agricultural Research Manager ARM7). 
branches, they were not significantly different from wood-chip piles from healthy branches in 2013 (Table 2).

Ascospores collected above wood-chip piles from cankered branches were compared to samples from above wood-chip piles from healthy branches. Differences in ascospore counts were analyzed by $\log$ transforming the data before analysis with Satterthwaite's two-sample t-test (SAS 9.1). Significantly more ascospores were found in 2012 above wood-chip piles from cankered branches than for wood-chip piles from healthy branches (Table 2). Although more ascospores were found above woodchip piles from cankered branches, they were not significantly different from wood-chip piles from healthy branches in 2013 (Table 2).

As a reference point for the study, an ascospore trap was also placed below EFB-cankered branches (a known source of inoculum) among 'Ennis' trees used in fungicide trials located $200 \mathrm{~m}$ east from the closest wood-chip pile. Ascospores were collected biweekly from mid-March to May and samples counted for cumulative total (Table 2). When compared to non-chipped branch piles with intact cankers, the cumulative number of ascospores detected above wood-chip piles from cankered branches was reduced by two to three orders of magnitude for both years.

\section{HAZELNUT TREE EXPOSURE}

Five healthy, two-year-old potted 'Ennis' hazelnut trees were placed among each pile of chipped branches, and at $6.4 \mathrm{~m}$ upwind and $6.4 \mathrm{~m}$ downwind from each source pile during the period of

\begin{tabular}{|c|c|c|}
\hline \multicolumn{3}{|c|}{$\begin{array}{l}\text { TABLE } 2 \\
\text { The cumulative number of Anisogramma anomala } \\
\text { ascospores captured in rainwater traps above wood-chip } \\
\text { piles from cankered or healthy (check) branches or below } \\
\text { intact diseased branches in } 2012 \text { and } 2103 \text {. Ascospores were } \\
\text { collected from March to May in both } 2012 \text { and } 2013 \text {. }\end{array}$} \\
\hline \multirow[b]{2}{*}{ Location } & \multicolumn{2}{|c|}{ Spore/m²/day (log scale) } \\
\hline & 2012 & 2013 \\
\hline $\begin{array}{l}\text { Above wood-chip pile from } \\
\text { healthy branches }\end{array}$ & $2.8 \times 10^{2} \mathrm{a}^{\mathrm{x}}$ & $2.7 \times 10^{2} \mathrm{a}^{\mathrm{x}}$ \\
\hline $\begin{array}{l}\text { Above wood-chip pile from } \\
\text { cankered branches }\end{array}$ & $6.4 \times 10^{3} \mathrm{~b}$ & $2.2 \times 10^{3} \mathrm{a}$ \\
\hline Below intact diseased branches $\mathrm{y}$ & $1.3 \times 10^{5}$ & $1.2 \times 10^{5}$ \\
\hline
\end{tabular}

${ }^{\mathrm{x}}$ Within each year, different letter indicate a significant difference based on Satterthwaite's two-sample t-test calculated in SAS $(P \leq 0.05)$.

$\mathrm{y}$ Ascospores captured below intact diseased branches for a fungicide efficacy trial that was conducted concurrent with the wood-chip pile study.

\begin{tabular}{|c|c|c|c|}
\hline \multicolumn{4}{|c|}{$\begin{array}{l}\text { TABLE } 3 \\
\text { Percent of Eastern filbert blight infected trees upwind, at } \\
\text { and downwind of wood-chip piles in } 2012 \text {. }\end{array}$} \\
\hline \multirow[b]{2}{*}{ Treatment } & \multicolumn{3}{|c|}{ Percent of infected trees $(n=15)^{x}$} \\
\hline & Upwind & Source pile & Downwind \\
\hline $\begin{array}{l}\text { Wood-chip pile from } \\
\text { healthy branches }\end{array}$ & 7 & 0 & 0 \\
\hline $\begin{array}{l}\text { Wood-chip pile from } \\
\text { cankered branches }\end{array}$ & 0 & 0 & 0 \\
\hline
\end{tabular}

${ }^{x}$ Not significantly different based on differences of least square means using a "split-plot-in-time" model in SAS PROC MIXED. susceptibility to infection, bud break through shoot elongation (March-June) in both 2012 and 2013. After the end of the exposure period, the potted trees were incubated in an unheated plastic greenhouse for 13 months to allow symptoms of EFB to develop. Each tree was examined for cankers the following summer on 15 July 2013 and 21 July 2014. One downwind set of trees in 2012 was inadvertently placed too close to a $20 \times 20 \mathrm{~m}$ brush pile with EFB-symptomatic branches (a known source of inoculum) that was scheduled to be burned before bud break but was not. As a result, there were subsequent cankers on all five of the trees closest to the brush pile while three out of five trees in the wood-chip pile were infected. This replication (wood-chip pile from cankered branches and its paired wood-chip pile from healthy branches) was removed from analysis due to outside contamination, so in 2012 there were only three replicates instead of four. Analysis was based on differences of least square means using a "split-plot-in-time" model analysis (PROC MIXED in SAS 9.1).

In 2012, only one upwind tree exposed to either the healthy or cankered wood-chip piles developed cankers (Table 3). All other trees remained healthy, whether upwind, downwind, or at any of the wood-chip piles. In 2013, none of the trees exposed to woodchip piles from healthy or infected branches developed cankers (data not shown).

In comparison, a group of 8 and of 16 non-treated 'Ennis' trees used in fungicide trials located $200 \mathrm{~m}$ east from the closest cankered wood-chip pile replicate were planted at the same time in 2012 and 2013, respectively. In these trials, cankered branches were suspended above all trees during bud break and resulted in $100 \%$ incidence and numerous cankers per tree both years.

\section{CONCLUSIONS}

Data from this research trial demonstrated that coarse chipping of hazelnut branches with EFB cankers reduces potential exposure to ascospores that result in canker development. Although viable ascospores were detected within and above wood-chip piles from cankered branches, susceptible trees placed within or downwind of these wood-chip piles did not become infected (Table 3 and 4). Infection of susceptible trees in the 2005 single wood-chip pile study probably resulted from inoculum sources outside of the study area since the low level of infection was similar both within and outside of the wood-chip area. Growers are advised to chip cankered branches into as small a particle size as possible to break up EFB cankers, encourage decomposition of wood chips, and limit possible interference with mechanical harvest in the fall. Because whole branches with EFB cankers can still be a potential source of inoculum (Heckert et al. 2014), cankered branches need to be chipped prior to bud break in the spring (Stone et al. 1992). This activity will help avoid burning restrictions in the winter, reduce carbon loading to the atmosphere, and help improve air quality during the winter season.

\section{ACKNOWLEDGMENTS}

This research was supported by the Oregon Hazelnut Commission, which is a Commodity Commission and agency of the State of Oregon under the Oregon Department of Agriculture.

\section{LITERATURE CITED}

Fagundes, M. 2015. Oregon outdoor burning guide. Oregon Dept. of Environ. Quality, Portland, OR. http://www.deq.state.or.us/aq/factsheets/04-aq005-openburneng.pdf

Gottwald, T. R., and Cameron, H. R. 1979. Studies in the morphology and life history of Anisogramma anomala. Mycologia 71:1107-1126 
Heckert, S., Pscheidt, J. W., and Stone, J. K. 2013. A quick and simple method to evaluate Anisogramma anomala ascospore viability. Plant Health Prog. doi:10.1094/PHP-2013-0509-09-RS.

Heckert, S., Pscheidt, J. W., and Cluskey, S. A. 2014. Disease incidence and ascospore dispersal from cut hazelnut branches colonized by Anisogramma anomala. Plant Dis. 98:834-838.

Johnson, K. B., Pinkerton, J. N., Gaudreault, S. M., and Stone, J. K. 1994. Infection of European hazelnut by Anisogramma anomala: Site of infection and effect of host developmental stage. Phytopathology 84:14651470 .

Johnson, K. B., Mehlenbacher, S. A., Stone, J. K., Pscheidt, J. W., and Pinkerton, J. N. 1996. Eastern filbert blight of European hazelnuts: It's becoming a manageable disease. Plant Dis. 80:1308-1316.

Pinkerton, J. N., Johnson, K. B., Theiling, K. M., and Griesbach, J. A. 1992. Distribution and characteristics of the eastern filbert blight epidemic in western Oregon. Plant Dis. 76:1179-1182.
Pinkerton, J. N., Johnson, K. B., Stone, J. K., and Ivors, K. L. 1998a. Factors affecting the release of ascospores of Anisogramma anomala. Phytopathology 88:122-128.

Pinkerton, J. N., Johnson, K. B., Stone, J. K., and Ivors, K. L. 1998 b. Maturation and seasonal discharge pattern of ascospores of Anisogramma anomala. Phytopathology 88:1165-1173

Pinkerton, J. N., Johnson, K. B., Aylor, D. E., and Stone, J. K. 2001. Spatial and temporal increase of eastern filbert blight in European hazelnut orchards in the Pacific Northwest. Phytopathology 91:1214-1223

Pscheidt, J. W., and Ocamb, C. M., sr. eds. 2016. Pacific Northwest Plant Disease Management Handbook. Oregon State Univ., Corvallis. http://pnwhandbooks.org/plantdisease/hazelnut-corylus-avellana-easternfilbert-blight

Stone, J. K., Johnson, K. B., Pinkerton., J. N., and Pscheidt, J. W. 1992. Natural infection period and susceptibility of vegetative seedlings of European hazelnut to Anisogramma anomala. Plant Dis. 76:348-352. 